\title{
SPECTRUM AND FUTURE SERVICES
}

\section{Chair: André Trindade - Engenheiro de Comunicação - ABRATEL}

The panel will present the current spectrum situation and the demand for future broadcasting services in Japan and Brazil. Regulators have the challenge of addressing the spectrum requirements of different sectors and, given the strong pressure in some countries to adopt $600 \mathrm{MHz}$ for broadband, the positioning of Anatel as a regulator of the Brazilian spectrum will be presented and discussed. We will also see how this issue has been conducted in international forums, with an emphasis on the Americas. Moreover, the panel will discuss the use of the VHF band by some channels.

\section{- POLICY AND VISION OF USE OF SPECTRUM IN JAPAN -AFTER ASO}

\author{
Speaker: Hiroyuki Ogawa - Director for Digital Broadcasting Technology, \\ Ministry of Internal Affairs and Communications, Japan \\ Japan completed ASO in March 2012. After ASO, some VHF and UHF bands that used by analogue- \\ TV has been re-allocated to other services. In the presentation, how the spectrum was re-allocated \\ after ASO in Japan and current issues related to the spectrum allocation towards the launch of $5 \mathrm{G}$ \\ mobile system are explained
}

- A DANGEROUS SCENARIO... Speaker: Paulo Ricardo Balduino - Diretor de Planejamento de TV/Espectro da ABERT

\footnotetext{
...is taking shape much more quickly than was expected where the use of the UHF band for broadcasting is concerned. Adding to the continually inflated projections for the broadband spectrum arising from inappropriate and biased studies by the ITU and large companies, the attitudes of the governments of countries in Region 2 are challenging both the decisions of the WRC 15, and the scope of the forthcoming WRC 19, which also puts at risk the validity of the decisions of a world conference of the ITU, an entity known for its consensual decisions. Global studies of demand cannot be used on a national basis, how does a country check in Recife override a globalized projection for
} 
traffic growth. And the efficient use of the spectrum remains a taboo. These issues will be dealt with to encourage discussions.

- SPECTRUM: THE VISION OF ANATEL

\section{Speaker: Leonardo Euler de Morais - Presidente do Comitê de Uso do} Espectro e de Órbita (CEO)

The President of the CEO - Spectrum and Orbit Use Committee - will present how Anatel thinks about the future of TV in Brazil and its vision on spectrum needs for current demand and new broadcasting technologies. He will also address the positioning and performance of the Brazilian administration in the international forums of the Inter-American Telecommunication Commission (Citel) and the International Telecommunication Union (ITU) on the spectrum used by broadcasting.

- THE ITU (INTERNATIONAL TELECOMMUNICATION UNION) AND WRC 2015 RESULTS (WORLD RADIOCOMMUNICATION CONFERENCE) Speaker: Ilham Ghazi - Head of Broadcasting Services at the
Radiocommunications Office of the International Telecommunication Union. In this live video participation, Ms. Ghazi will make a brief introduction about the International Telecommunication Union so that the importance of this organization can be understood for broadcasters in Brazil and Latin America. The results of the WRC 2015 will also be presented with respect to the spectrum used by the broadcasting and possible scenarios for WRC 2019 and 2023 will be presented. The process of regional coordination of VHF and UHF frequencies for Central America and the Caribbean has already begun and Brazil, for border issues, also participates. The ITU representative will also talk about the importance of this process.

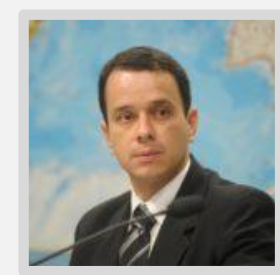

André Trindade - Engenheiro de Comunicação - ABRATEL

Network Engineer by UnB, with specialization in Public Management and Information Security. Trindade is a member of the Brazilian delegation to the Inter-American Telecommunication Commission (PCC.II CITEL). In addition, he is a full member of Gired -.Grupo de Implantação do Processo de Redistribuição e Digitalização de Canais de TV e RTV

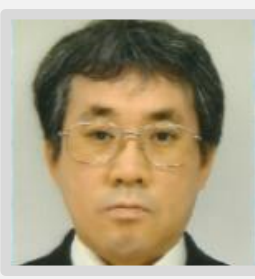

Hiroyuki Ogawa - Director for Digital Broadcasting Technology, Ministry of Internal Affairs and Communications, Japan

Hiroyuki Ogawa is currently a Director for Digital Broadcasting Technology, Ministry of Internal Affairs and Communications, Japan. He is in charge of technical assistance for the ISDB-T adopted countries and international promotion of 4K/8K technology. $\mathrm{He}$ joined the Ministry in 1998 and has the extensive experience of coordination of R\&D projects, regulations, and international affairs in the field of telecommunications and broadcasting. He was also dispatched to the Embassy of Japan in Russia as a telecommunications attaché. He graduated from the University of Tokyo with a degree of B.E. in electrical engineering. He is also an avid amateur radio operator. 

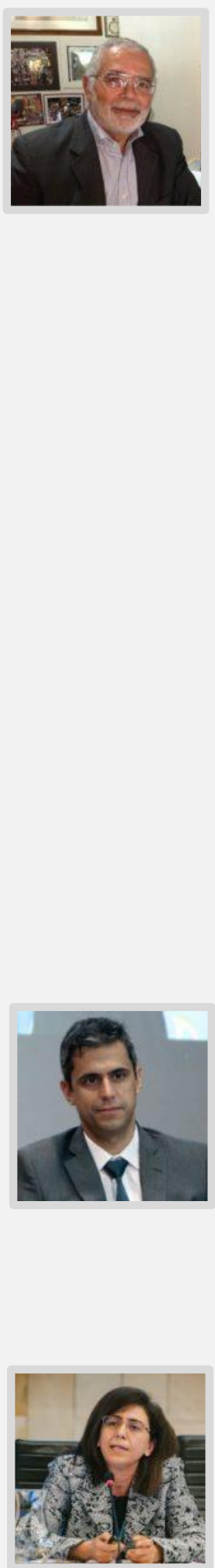

\section{Paulo Ricardo Balduino - Diretor de Planejamento de TV/Espectro da ABERT}

Paulo Ricardo H. Balduino, born 1949, electronics engineer from the University of Brasilia, married, with three children. Oversees the work of the Brazilian Association of Radio and Television Broadcasters - ABERT, focusing on the policy, planning and use of the electromagnetic spectrum. He worked at the Ministry of Communications as coordinator of international regulatory activities in different forums of the International Telecommunications Union - ITU and the Inter-American Telecommunication Commission - CITEL, having created, as far back as 1974 and 1975, the process for Brazil's participation in the work of the ITU and the CITEL, including Brazilian commissions of studies designated at the time as CBR.s and CBTT.s, nowadays restricted and renamed CBC.s. He has headed up Brazilian delegations at several meetings, assemblies and conferences of the ITU and the CITEL on a range of subjects, including planning for the use of the spectrum for different services. When the $12-\mathrm{GHz}$ Satellite Broadcasting Service was in the planning phase, he presided over a group of experts who came up with the planning algorithms and the procedures for updating the plan. He was a founding member of the "National Infrastructure Committee on Information of ANATEL (C.INI - ANATEL), where he was responsible for the Telemedicine Group, having carried out his activities to an advanced level of development. He has represented ANATEL on several forums and working environments on this issue. He was Director and Co-founding Partner of the company, Spectrum Latino America, a joint venture with European company, Spectrum Strategy Consultants

\section{Leonardo Euler de Morais - Presidente do Comitê de Uso do Espectro e de Órbita (CEO)}

Leonardo Euler holds a degree in Economics and a Master's degree in Economics from the University of Brasília. He has been a career servant of Anatel since 2005. Approved in the first public exam held by the Agency, where he served as head of the Technical Advisory. He is currently a member of the Board of Directors of Anatel and Chairman of the Spectrum and Orbit Use Committee (CEO).

\section{Ilham Ghazi - Head of Broadcasting Services at the Radiocommunications Office of the International Telecommunication Union}

Graduated in Radiocommunications Engineering from the International Aviation Institute of Kiev, Ukraine and a Master's degree in Business Administration from the Ecole polytechnique Federale in Lausanne, Switzerland. She is currently charged by ITU to lead regional coordination meetings to allow administrations to have additional frequencies in the Band $470-694 \mathrm{MHz}$ and facilitate the release of the first and second digital dividends.

Cite this article:

Trindade, A., Ogawa, H., Balduino, P. R., Morais, L. E. de and Ghazi, I. ; 2017. Spectrum and Future Services. SET EXPO PROCEEDINGS. ISSN Print: 2447-0481. ISSN Online: 2447-049X. v.3. doi: 10.18580/setep.2017.2. Web Link: http://dx.doi.org/10.18580/setep.2017.2 